\title{
Participation of the Beginner Teacher in Social and Cultural Space of the School: On the Need of Transgressive Opening to Change
}

Being in school means being in culture (Czerepaniak-Walczak, 2018, p. 72)

\begin{abstract}
The text discusses the issue of rooting of a beginner teacher in the social and cultural space of the school. The article is intended to raise awareness about possible fields of tension in the school culture, which - as identified in the experience of teachers - may serve as a barrier for functioning of a novice at school. In the beginning I presented a short discussion of the essence of school culture, and pointed out to possible presentation of problems related to functioning of a beginner teacher in it. In this background I presented assumptions and results of my own studies devoted to looking for an own place in school culture by a novice. From the perspective of teachers, when referring to their opinions I presented what types of own experience may be identified in the process of participation in school life and what types of anchors are used by novices. The discussion develops the thesis that due to multiplicity and locality of school cultures, a novice cannot learn them during their academic education, but they may be transgressively open to the notion of difficult embedding into the social and cultural space of school. The data obtained show that the teachers try to understand their own experiences and juxtapose them with their limited knowledge about school life when they start their work. The results show that they are motivated to take transgressive actions, and actively look for reference sources to formulate the interpretation framework and define a situation which is new to them. This can be understood as an attempt to immerse in the social world of the school and become an inherent part of the school culture.
\end{abstract}

1 Institute of Pre-School and School Education, The Pedagogical University of Cracow, Poland. E-MAIL: magdalena.grochowalska@up.krakow.pl ORCID: 0000-0002-3580-5525 


\section{Keywords:}

beginning teachers, school culture, professional socialization, transgression, types of anchors

\section{INTRODUCTION}

The title mentions two complementary categories, around which the content of the article is built. The beginner teacher draws attention to the specific features of the beginning of the professional career, while the social and cultural space of school points out to the novice's need to understand the logic of social world of a school. Under the notion of the social and cultural space of a school I mean two references. The first one is the culture of the organisation, that is, the school that is described, analysed and interpreted in the internal perspective. The second one is the culture of the profession, in this case - the profession of a teacher (Nowosad, 2019).

In the topic discussed in the text, I devote particular attention to the problems of acknowledging the social world of a school by a novice, learning its logics, openness to new experience. Talking about participation in social and cultural space of school, I refer to the interpretative approach in survey of organisation, which searches for local meanings explaining the manner of construction of "the organisational reality” (Kołodziej-Durnaś, 2012, pp. 146-147). I assume that the context provided for the social learning of a profession is the space related to participation in school culture that is acknowledged, acquired and co-created by a novice. On this basis the thesis is established that due to multiplicity and locality of the social and cultural space of school, it is impossible for a novice teacher to learn the principles of participation in the school culture during their academic education, but they may be ready for transgressive opening to the culture, ready to face the difficulty of embedding into it, feel the need to understand the school life. This text is aimed to present how it happens that a novice moves from peripheral areas into the centre of social and cultural practices in school, that is the recognition and description of possible ways and strategies for a novice to embed into the school culture.

Due to the wide scope of the problem, the analysis performed here presents only a small scope of the examined phenomenon and is a part of a wider survey on becoming a teacher. Assuming that the social and cultural environment of school is the context of thinking patterns adopted by a teacher, as well as reflections and undertaken activities, in the text I point out to selected contexts of novice's presence in school culture. 


\section{SCHOOL IN CULTURAL PERSPECTIVE}

The literature reveals a variety of concepts and approaches related to the school culture. As this term has a broad meaning and is ambiguous, it is defined in different ways by researchers. In the perspective of problem-related and historical analyses, it may be concluded that there is no unique arbitrary definition of the school culture (Nowosad, 2019). We may assume most generally, like Maria Dudzikowa (2010, p. 220), that school culture means material, immaterial and symbolic elements of the "life of the organisation" that do not develop linearly, and the results of development cannot be foreseen and arranged.

In terms of the cultural space of the school, the focus should be on interaction processes which create and maintain meanings common to a given group of teachers and encourage specific behaviours. The areas of symbolic messages and meanings, hidden for outside observers, are built as a result of everyday interactions based on social context and cultural order (Pawłowska, 2012, p. 160). Provided that the school culture expresses people's deepest needs and the way the meaning is assigned to their experiences, it is assumed that the school culture provides many, both individual and common, worlds which are assigned the meaning reflected in everyday practice. Although each teacher perceives, interprets and experiences the surrounding reality in a different way, the teachers are also part of a social world shared with others, with the rules which require submissive approach. Therefore, more precisely, school culture can be understood as a network of basic assumptions reflected in social and organisational norms, values, beliefs, behaviours, rituals, myths, ways of communication and symbols adopted by a given group of people in connection with joint work, solving problems, taking challenges and learning how to handle external adaptation and internal integration. These assumptions are subject to renewal. Senior teachers "teach" neophytes of "how things are done” (Nowosad, 2019, p. 113), which means that the assumptions are passed on to the new members of the group as the appropriate way of perceiving, thinking, and feeling.

Problematizing the emancipatory potential of school culture, Maria Czerepaniak-Walczak (2018, p. 80) stresses that it is the particular space for development of a person that is created of beliefs, opinions, attitudes and relations, written and unwritten principles. It is the space that shapes every aspect of operation of a school as institution, organisation and community. It should be emphasized that the school culture understood in this way has its local specifics related to the fact that "[...] it is deeply embedded in the 'matter', in layers of meanings and behaviours [...]. It is present in bodies and walls [...]” (Kołodziej-Durnaś, 2012, p. 311). 
However, researchers of organisational cultures point out to the possibility of co-existence of various dimensions of the same culture, and then they speak about "fragmented culture". Next to transparent, public, easily recognizable culture, there is the other one that is hidden, deep and much more difficult to be identified. For example, if one can observe involvement, harmony and shared responsibility in the first one, in the latter people can express their dismay or indignation with the conduct of others. Recognition of both dimensions, necessary for participation in the culture, is possible only by means of long-term and involved participation in life of an organisation (Morgan, 2005, pp. 137-138). The phenomenon of coexistence of cultures refers also to school (e.g., culture of teachers, pupils, parents, school administration that are in mutual relationships, which creates the "multiculture" of a given school). However, there is always the dominant culture that has smaller or bigger impact on the other ones (Czerepaniak-Walczak, 2018, p. 85).

Participation in the school culture requires both sharing the cognitive perspective with the group of teachers and self-identification in the personal and professional dimension. The elements of the social and cultural world of the school are arranged in compliance with specific logic and criteria of hierarchy by means of personal interpretation framework. Its elements include self-awareness and subjective teaching theory. They enable recognition of patterns and mechanisms of operation adopted in a group, and in case of a novice teacher they provide answers to two questions: how do I cope in the new situation, and why do I think that it is an efficient manner of operation (Kelchtermans, 2005). According to the thesis that "the culture is not a harmoniously agreed principle, but 'fragmented' unity, and members of an organisation are both separate and united” (Kołodziej-Durnaś, 2012, p. 171), it may be assumed that although construction of interpretation framework is of individual nature, their contents is the result of the social resources of a group.

If we assume that members of the school culture cannot feel it, since it is everywhere around, it is a part of themselves (Nowosad, 2018, p. 49), the position assumed in school by a novice draws attention.

\section{BEGINNER TEACHER AT SCHOOL}

Researchers of professional development of teachers state that only few experiences have such a huge impact on personal and professional life of a teacher, as those in the first years of work in that profession (Michalak, 2007, p. 338). Becoming a teacher is considered to be a process that depends both on changes in personality and interaction between a teacher and the context, that is, a school as 
an organisation with its various actors (Kelchtermans \& Ballet, 2002). The meaning of interactions or beliefs and actions undertaken by a novice depends on the nature of such interactions, since a novice is not a passive recipient of norms and values, but they always interpret them in a specific manner. This process cannot be normalized, standardized and takes place in the social and cultural space of the school. It is related, for instance, to following of acceptable norms, patterns of conduct, beliefs, values that have been formed by members of a community, as well as to reflective and critical construction of own hypotheses and theories and recreation of those that have already functioned socially. As far as beginner teachers are concerned, becoming a member of school culture takes place mainly through adjustment. Only acknowledgment and understanding of mechanisms that govern the culture, which is pointed out by M. Czerepaniak-Walczak (2018, p. 85), makes it possible to make a decision on adjustment to it or its intentional transformation, adaptation or emancipation. The above-quoted author also believes that regardless of the manner of becoming a member of culture, embedding takes place by means of experiencing of the culture, which should be understood as experiencing and understanding its elements and relationships among them (2018, p. 77).

The process of embedding into school culture does not take place overnight, it takes time and requires teachers' participation and involvement, rooting (cf. Piorunek, 2009, p. 307), anchoring (cf. Kędzierska, 2015) in their professional roles. Borders of participation in social and cultural space of school are related not only to time, but also conditions of work, relationships of power, school staff, present conflicts or type of chosen rationality in thinking about school. A barrier may have a form of a specific closure of a school community against a novice, which is related to non-acceptance of changes, new things and things that do not resemble routine. Consequences refer, for instance, to a threat of professional burnout syndrome, disputes over competence between younger and older teachers, which replace support that would be satisfactory for both parties. Moreover, a novice is in a difficult situation since communities resign from their traditional bonds and internal relations (Aarts, Kools, \& Schildwacht, 2020), in result of which socialisation of new members is not controlled.

Entering the labour market is surely a difficult transgressive situation in early adulthood (cf. Grochowalska, 2015), where conduct of an individual is generated by competences possessed by them, including transgressive competences allowing for openness to changes (Czerepaniak-Walczak, 1999, p. 64). Transgressive openness is an element motivating people to changes in their development, overcoming difficulties and involvement in new challenges, but it requires particular sensitivity, self-knowledge, self-recognition, transgressing oneself (Łukasik, 2018, p. 31). 
Transgressive competences related to self-realisation and designing own future enable transgressing of barriers and borders - social, temporal and material ones, they motivate to exceed borders of the world that already exist (e.g., of the professional world). Transgressive activities such as "I know I can" in human functioning perform other function than protective and adapting activities such as "I know I have to". The first ones are directed at transformation of reality, which requires, for instance, replacement of old habits with creative activities (Kozielecki, 2002), while the latter enable adaptation to the environment and have a form of routine and reproducing activities.

A question may be asked, what activities are particularly necessary for a novice to find their place and teach in the school culture, to be ready for multiplicity and comprehensiveness of possibilities, and simultaneously contribute effectively to transformation of both the self and the school?

\section{ASSUMPTIONS OF THE RESEARCH PROJECT}

Talking about embedding of a novice into the school culture, a departure from the functionalistic way of thinking about the teacher and assumption of the perspective of symbolic interactionism (Blumer, 2007) attracts attention to interactive and personal contexts of that process, emphasizing the meaning of experience of an individual that enables creation of self-knowledge. Therefore, the analyses presented here, that are a part of a wider research, are based on interpretative approach enabling recognition of subjectivity of adopted meanings.

Finding own place in the school culture requires from a novice to refer to gathered experience, including taking into account its three aspects (Ablewicz, 2015, pp. 12-13): experiencing related to emotions, reflecting, and learning resulting in drawn conclusions. It means that in attempts of recognition of the aspect of participation in the school culture, one should pay particular attention to what is recognized by novices, how their interpret situations, other practices, activities performed by them in order to determine and then ensure working conditions acceptable for them, to what extent they are satisfied with undertaken activities. One should also remember that things learned by a person may contribute to active embedding in reality, but also be a source of discouragement.

With regard to the category of socio-cultural space of the school referred to in the title, practice should be understood as a discourse constructed by subjects and relating to their everyday activities. The discourse assumes mutual interactions between the subjects involved in the construction of the meaning of actions and 
the ways the activities are arranged (Barbier, 2016, pp. 114-116). The universe of discourse understood in this way is a communication platform in which participants share a common perspective on how they perceive reality, learn how to deal with a given action and pursue their own interests, and create a social world (Kacperczyk, 2012). Distinctive features of the social world of school include, for instance, non-obviousness, elusiveness, volatility, uncertainty. Each social world adopts a special terminology and uses various rhetorical figures to stand out from other worlds. A novice which enters the social world constructed by teachers starts to adopt its assumptions, to form the interpretation framework and to build professional identity. The confrontation of everyday work with expectations causes the feeling of helplessness and lack of achievement (Kędzierska, 2012, pp. 346-347), but at the same time triggers learning mechanisms (Confait, 2015).

In reference to the presented remarks, the aim of the undertaken attempt of research was to learn and understand meanings attached by beginner teachers to their experience - in the context of acquired knowledge, undertaken activities, motivations and emotions - related to the first years of work at school. Thus, the aim was not to describe school structures with their local conditions, but identify experiences gathered by people embedded in them. The researched issue gained a form of the following question: what facts and situations cause rooting felt by teachers in the social and cultural space of the school? Operationalising the category of social and cultural space, attention was focused on two dimensions: types of own experiences identified with participation in school life and scopes of understanding of situations, practices identified with securing of own conditions of work.

The research materials come from free, partially structured interviews. This technique makes it possible to respondents to present the manner in which they see the world, while a researcher may make an attempt to understand experiences and perception of the world by his/her interlocutors (Lofland et al., 2009, pp. 131-133). The manner of identification of the category of school culture - in reference to pedagogy, anthropology, sociology and theory of organisation - defined the scope of the main questions. Interviews were conducted with 24 female teachers of grades 1-3 of primary school (in Małopolskie Voivodeship). Purposeful sampling was based on the criterion of length of service (third year of work), professional advancement degree (completed internship ${ }^{2}$ ), continued education (during $2^{\text {nd }}$ degree studies).

2 Research was conducted in years 2014-2015. According to the legal regulations on professional advancement, the respondents had the degree of a contract teacher at that time. 
Having acknowledged all material, I selected fragments of answers that were grouped on the basis of similarities and differences in meaning. Thanks to this, I obtained descriptions of experiences considered to be important for respondents at the early stage of work at school. Then I performed analysis of experience sequence schemes (Lofland et al., 2009).

\section{FINDING OWN WAY IN THE SOCIAL AND CULTURAL SPACE OF SCHOOL}

The teachers talk about their feelings related to beginning of work, entering into a new team of people in various ways. Searching for opposite themes in utterances, I noticed that when talking about "finding own way", they often use a metaphor. The research shows that used metaphors are related to conceptualisation of the teaching process, adopted work programme and manner of work in a team (Mahlios, Massengill-Shaw, \& Barry, 2010). They reflect many features, emphasize specific and characteristic features of culture, "they are mental linguistic structures, ensuring insight into thinking processes” (Czerepaniak-Walczak, 2018, pp. 93-94). Therefore, I assumed that metaphors may be meaningful for functioning of a novice in the school culture, they will help to understand novice's experiences. I typified experiences discussed by the respondents and related expectations that they considered significant for organisation of their own professional activity.

I will refer here to three selected experiences that may be described metaphorically as: The first pancake is always spoiled (6); Waste of time and money (5); There are two sides of every story (5), Like a child lost in the woods (4). ${ }^{3}$

\section{THE FIRST PANCAKE IS ALWAYS SPOILED (6)}

Replies of respondents show their uncertainty, anxiety, or scare related to the fact that they do not know the rules of conduct in the beginnings of their work. Although teachers valued highly their practical skills, involvement, responsibility, discipline, which encouraged them to solve difficult situations, they experienced strong tensions. That is why they expected assistance in solving everyday problems, they needed a tutor/mentor, since the internship supervisor did not fulfil their role, and formal principles of the internship were not satisfactory for them. It is clearly visible that they fought against uncertainty, which they could overcome with support of a member of the teaching staff. These are the examples:

3 Accepted metaphors come from the in vivo code. The number of statements in which the given thread was recognized is given in brackets. 


\begin{abstract}
"At the beginning I was simply scared. Not of the work in class, because I was rather well prepared, but in general of everything. I didn't know anybody here, I didn't know what are the rules (.) I couldn't talk to anybody. Probably, my biggest problem was that such a young teacher cannot say anything”. (4) ${ }^{4}$

"[...] and also my supervisor, he is not worth talking about. Fortunately, Jola, the teacher of another class, visited me once, and she really showed me the rules in the school. I learned slowly and now everything is good, things are getting better”. (9)
\end{abstract}

Respondent teachers do not agree on acting without any reflections about it, they want to participate in the life of a school, which is a difficult task even in a small group of teachers. It is visible that during time devoted to learning of the profession in the place of work from the experience of others they go beyond their uncertainty. Things will be getting better now - it is a pattern of interpretation, according to which only initial recognition of the group culture makes it possible to undertake satisfactory interactions (Czerepaniak-Walczak, 2018, pp. 173-177). According to the replies, certain manner of determination may be an efficient way to cope in this difficult period of work for them.

\title{
WASTE OF TIME AND MONEY (5)
}

Experience corresponding to this statement consist of two opposite themes. Although teachers realise fields of own activities that in their opinion are pointless and not worth talking about, they encourage the teachers to undertake opposite activities.

Some teachers perceive such activities as a nasty obligation, emphasizing coercive nature of activities related to professional advancement. In such context, the purpose of work in a team of teachers is mainly to obtain tools for efficient organisation of pedagogical practice. For example:

\footnotetext{
"[...] of course, I used workshops or class visits, but sometimes it was really a waste of time! I did not benefit much, I went there and watched. [...] I want to know as much as possible, I know that I still have a long way ahead of me, but I think that at the beginning I should receive some materials to work on. I do not mean any arrangements, but some (.) ordinary assistance”. (17)
}

Expectations of such time resemble a demanding attitude. It may be assumed that it is related to overloading, but it may also derive from no reflections on professional activities. Research of expectations of novices about the environment of work, collegiality and the need of being recognized show high expectations about

4 The number means the number of interview where the quotation was found. 
organisation of the special and material environment of work (Gavish \& Friedman, 2011). The quoted teacher has no doubts, either, about who and why should guarantee assistance to her.

Another theme of undertaken activities that are initially assessed as not worth attention is related to perception of possibilities of personal development in such type of activities. There are three teachers in this group, who - while describing the beginnings of work - pose themselves in another context, in opposition to the one quoted above. They see a possibility of development, but personal development, even in "pointless" activities. They talk about work in the context of fulfilment of own needs rather than response to external expectations that are, for instance, related to achievement of professional promotion. One of the teachers says:

“I have set a goal for myself, I don’t know if I manage but I'd like to work here as long as possible. Sometimes it seems to me, yyy, I cannot define it, that we make something pointlessly, but I take the risk, I look for something new that I can learn”. (6)

\section{THERE ARE TWO SIDES OF EVERY STORY (5)}

The respondents talk about situations when they experience particular care from others, which they accept with pleasure, but at the same time they have doubts about the scope and the duration of period when they can accept such care. Concerns are related to experienced limitation of own independence, which is a particularly appreciated value. Too much monitoring of their work, even mothering (1), may result in reduction of the sense of professional responsibility or open, creative approach to work. In the behaviour of their "supervisors" they notice interpersonal errors, they assign the dominant functions in relationships to them, inclinations to steer other people, to management or even to despotism. One teacher describes her doubts in the following way:

\footnotetext{
"Probably I should feel comfortable with such supervision, assistance provided to me every day, I did not bear the full liability. But I didn't want to work in the way as if I was controlled every time. I was completing my internship, I felt that I should be more independent (.) I had also problems when talking to parents, as if I was still the new one. Kindness, assistance, some kind of care is good at the beginning, but then finally one has to bear the liability for oneself”. (7)
}

The monitoring mentioned above means probably that things understood by an experienced teacher as support and care may be treated by a beginner as limitation of independence and the right to decide on own activities. The main motive 
of learning of a new group member who tries to become a part of the group is becoming more recognizable by the professional community (Gavish \& Friedman, 2011). Undoubtedly, this task was more difficult for the quoted teacher because of too much care offered to her.

\section{LIKE A CHILD LOST IN THE WOODS (4)}

Such experiences are raised by the four teachers. They indicate, albeit to varying degrees, that they see the contradiction between their expectations for teacher's work and the events in which they participated. The passages relate to surprise, amazement, but also confusion due to ignorance of the new workplace:

"I really wanted to stay there, but it was difficult. Some matters, certainly those handled outside the classroom, were kind of hidden from me, shrouded in secrecy. It was really difficult for me to figure it out, to understand what is done, by whom, and how”. (23)

The subjects feel anxiety, and it seems that this is not due to how the educational process is arranged with regard to the students and the school classroom, but rather due to the concern about how other teachers would judge them. We can clearly see how a novice struggles with a sense of uncertainty, a feeling which can be overcome if positive reinforcement is delivered to them:

"This was not what I thought. I did not know what I expected. One time, I was indecisive and confused. Another time, I could see the light at the end of the tunnel and thought that everything would be fine over time. My biggest concerns were probably that they would think I was weak, young and unprepared. Fortunately, I worked with $\mathrm{X}$. She is... amazing. I really feel she guided me through all of this. She gave me the instructions on what to do, how to do and when it is worth it. She introduced me into this and showed me how to work in this school. In fact, it is thanks to her that I know all these things I did not know before. She encouraged me to get involved in various projects and I think it helped me to change my attitude". (1)

This quote shows that the teacher definitely appreciates the opportunity to learn from others. The presence of a "significant other", incorporating the activities of the student and the activities of the mentor for the sake of common goals, helps a novice to adopt new definitions and interpretations in the social world of the school (Kędzierska, 2012, p. 201).

When a novice experiences school as a workplace, they perceive the social world of the school - established by people who take action and create discourse in this respect - as a new and unknown context. To learn the logic of action used in this context requires the support of experienced participants of this context 
and time, especially since the beliefs previously formed are not subject to rapid change, in particular in the first years of work (Mahlios, Massengill-Shaw, \& Barry, 2010).

Experiences of teachers related to searching for own place in the organisational culture of the school are illustrated by descriptions of situations that, in their opinion, contributed to embedding into the culture. The responding teachers referred to two types of anchors, out of anchors used for transformation of temporary identity assigned by a professional group, which were identified by Hanna Kędzierska (2015, 2018). The first one uses high self-assessment of the starting capital of a career. Although in every day practice the teachers referred to the trial-and-error approach, they had a very high sense of competence in respect to undertaken professional activities. The other type of recognizable anchor is executed by adaptation and mimetism, which means that novices chose reproductive manners of operation learned during their academic education or observed in case of other teachers. No phenomenon of anchoring in family commitments was observed in case of the respondents.

It appeared, however, that they talk about anchoring, which I called contesting from working perspective (4), that results from disagreement on the state of things encountered by them, inability to be placed in the school culture. A point of reference for a novice in this case is the belief that she can do something even if she does not point to high assessment of the starting capital of the career and does not choose mimetism. Teachers then talk about willingness to perform activities that are radical but qualified positively from the moral perspective, and they lead to the change, "to the fact that they will feel better". This position was illustrated by the following words:

“I didn't care for anything at all, I had to do something with that, I didn't want to work more in such a way. I felt bad as a human being. I knew that it could be done differently, that I could change it, but I didn't assume that I can, and that I will manage [...]”. (20)

The declaration "I have to do something with it" does not result from protective activities but shows motivation to transgressive activities. Because openness to change requires knowledge about oneself, self-recognition, concept/vision of self, projection of own future, transcending oneself. This is, according to M. Czerepaniak-Walczak (2018, p. 177), transgression towards satisfaction and happiness, that is one of directions of change in the school culture. 


\section{CONCLUSIONS}

It may be concluded from the analysis of the content of responses that teachers have a need to get familiar with the life of the school, understand the specific characteristics of own experience, values, patterns and principles, which may show that they are open to changes. The identified and metaphorically described experiences of the teachers reveal two opposing ways of novices' behaviour. On the one hand, they are open to new experiences and expect support in the process of immersing in the school culture (although how this support is valued varies). In my opinion, these expectations are due to the need of sharing the perspective of the world of school. On the other hand, they are reluctant to share their concerns with others, and this can be why they find it difficult to participate in school life. They may choose not to admit that something is difficult and that they need help due to the fear of being judged by others. Avoiding support, even if available, may be due to the lack of trust in other teachers or the principal. In interpersonal relationships, trust is the foundation for building a sense of security determining the novice's involvement in new activities (Tołwińska, 2011).

The research material reveals the need to draw on the experience of other teachers. Despite being motivated to change, the teachers feel lonely, secluded and deprived of opportunities for feedback. Based on the data obtained, it should be noted that there is a need to develop practices which help novice teachers adapt to the school community. If social expectations are higher than the novices' own perception of their work, they find it difficult to understand the situation (Confait, 2015) and, as the data obtained indicate, may reject the patterns of behaviour developed in a given culture and concentrate their efforts on satisfying their own interests. Therefore, it can be assumed that the more novice the teacher is, guided by their own expectations, the more they are open to the need to understand the logic of the social world of the school, effectively searching for their own pedagogical path by following both clear and hidden cultural patterns adopted by a group of teachers. Acquired data point out to dynamics of decisions made by teachers who choose various anchoring mechanisms in order to find their place in the social and cultural school environment that is new to them.

Presented results of research entail consideration of the type of support given to beginners. Social support that is needed according to declarations of teachers plays a role of a buffer, in particular when requirements of a situation are higher than possibility of control on the side of an individual. However, the respondents do not expect "mothering", the feature that is assigned to the contemporary generation of young adults. The reasons of such situation may be found in professional 
responsibility that is born regardless of the number of years of service and a need to "cope” on one's own in everyday circumstances. It may be said that independence is a timeless value because young teachers who participated two decades ago in the research performed by Wanda Dróżka (2004, pp. 100-101) also said that they wanted to be themselves in everything they do.

Received data confirm Eugenia Potulicka's (2016) thesis that support and assistance provided for a novice is not enough for successful process of leaning and inculturation in school organisation. When discussing active formation of professionalism and teacher's identity, the quoted author points out that the process of entering into the school culture, understood as introduction to the profession, provides the ground for life-long learning. Thus, support should be aimed at promoting development in novice's career and in teaching. Madalińska-Michalak (2016, p. 49) asks about the role of the school in the development of teachers and emphasizes the need to build communities oriented towards development and integration. These communities can only exist if the consent to create a culture of learning is given. The author emphasizes that learning is not a separate activity, possible only after the teacher „,...] stops getting involved in other activities. The teacher's learning has a socio-cultural character [...]". This means that the patterns of learning and thinking are determined primarily by the social environment and school culture. Being in the social space of the school, the novice learns through interaction and develops communication practices within the group which, as one of the carriers of culture, are related to the oral form of communication and to the ritualized communication (Ollivier, 2010, p. 228).

Embedding in school cultured, extending fields of activities related to transgression of borders, acknowledging principles, behaviours, ideas is not an imposed task. As it is critically observed by M. Czerepaniak-Walczak (2018, p. 174), transgression starts always from "understanding of obvious or imagined limitations in what is here and now. From understanding of specific characteristics of own experience, ideas, values, norms present in the culture, patterns, figures and opinions”. The thesis on multiplicity and locality of social and cultural space of school, that was presented in the beginning, results in the fact that during their academic education a novice cannot learn the principles of participation in the school culture, but they may be prepared to face the challenge of embedding into the culture. It entails the statement that this task requires activity and openness of a novice teacher and readiness of other teachers for presence of a novice in school culture. The research on the condition of identity, own and collective image of teachers, which was performed by Henryka Kwiatkowska (2007), enabled recognition of a type of identity promoted in the organisation of social life and educational systems. It 
appeared that due to high level of objectivization of teachers they prefer external work management and they feel bigger comfort of work in case of strictly defined assignment of tasks. Responding teachers do not feel such need. Therefore, it is worth considering, according to H. Kwiatkowska (2007, p. 29), how much is the school ready to "demand made for an autonomous teacher". In the context of the responses, it may be assumed that in order to overcome norms of conduct adopted in some schools, rather re-adaptation of teachers working there than adaptation of novices is necessary.

At the end of my reflection I want to point out to the problem that I leave without an answer. It is expressed in the question: how much school cultures are transgressively open to novices characterised by strong involvement, need of independence and overcoming standards, willingness to bear responsibility understood as co-participation, who voluntarily act according to the principle "I can, although I don't have to".

\section{References}

Aarts, R., Kools, Q., \& Schildwacht, R. (2020). Providing a Good Start: Concerns of Beginning Secondary School Teachers and Support Provided. European Journal of Teacher Education, 43(2), pp. 277-295. DOI: 10.1080/02619768.2019.1693992.

Ablewicz, K. (2015). Doświadczenie pracy - antropologia oraz aksjologia osobistych i społecznych relacji w perspektywie rozwoju człowieka. Horyzonty Wychowania, 14(30), pp. 11-29.

Barbier, J.M. (2016). Leksykon analizy aktywności. Konceptualizacje zwyczajowych pojęć. Trans. E. Marynowicz-Hetka. Łódź: Wydawnictwo UŁ.

Blumer, H. (2007). Interakcjonizm symboliczny. Perspektywa i metoda. Trans. G. Woroniecka. Kraków: Zakład Wydawniczy NOMOS.

Confait, S. (2015). Beginning teachers' challenges in their pursuit of effective teaching practices. Cogent Education, 2(1), pp. 1-18. DOI: 10.1080/2331186X.2014.991179.

Czerepaniak-Walczak, M. (1999). Kompetencja: słowo kluczowe czy „wytrych” w edukacji? Neodidagmata, 24, pp. 53-66.

Czerepaniak-Walczak, M. (2018). Proces emancypacji kultury szkoły. Warszawa: Wolters Kluwer.

Dróżka, W. (2004). Młode pokolenie nauczycieli. Studium autobiografii młodych nauczycieli polskich lat dziewięćdziesiq̨tych. Kielce: Wydawnictwo UJK.

Dudzikowa, M. (2010). Esej o codzienności szkolnej z perspektywy metafory. In: M. Dudzikowa, \& M. Czerepaniak-Walczak (Eds.), Wychowanie. Pojęcia - Procesy - Konteksty. Interdyscyplinarne ujęcie. Vol. 5 (pp. 203-246). Gdańsk: GWP.

Gavish, B., \& Friedman, I.A. (2011). Novice Teachers as Organisational People: Expectations of a Professional Work Environment, Collegiality, Recognition and Respect. Educational Studies, 37(4), pp. 451-467. DOI: 10.1080/03055698.2010.540891. 
Grochowalska, M. (2015). Od wiedzy do działania: praca zawodowa w doświadczeniach początkujących nauczycieli edukacji przedszkolnej. Przegląd Pedagogiczny, 1, pp. 8597.

Kacperczyk, A. (2012). Świat społeczny. In: K.T. Konecki, \& P. Chomczyński (Eds.), Słownik socjologii jakościowej (pp. 276-278). Warszawa: Difin.

Kelchtermans, G. (2005). Teachers’ Emotions in Educational Reforms: Self-Understanding, Vulnerable Commitment and Micropolitical Literacy. Teaching and Teacher Education, 21(8), pp. 995-1006. DOI: 10.1016/j.tate.2005.06.009.

Kelchtermans, G., \& Ballet, K. (2002). The Micropolitics of Teacher Induction: A NarrativeBiographical Study on Teacher Socialisation. Teaching and Teacher Education, 18(1), pp. 105-120. DOI: 10.1016/S0742-051X(01)00053-1.

Kędzierska, H. (2012). Kariery zawodowe nauczycieli. Konteksty - wzory - pola dyskursu. Toruń: Wydawnictwo Adam Marszałek.

Kędzierska, H. (2015). Novice Teachers: The Process of “Anchoring”in the Teaching Profession. Forum Oświatowe, 27(2), pp. 59-73.

Kędzierska, H. (2018). Socjalizacja profesjonalna nauczycieli na starcie kariery zawodowej - druga strona medalu. Zarzq̨dzanie Publiczne, 1, pp. 75-89. DOI: 10.4467/20843968ZP .18.006.8235.

Kołodziej-Durnaś, A. (2012). Kultura organizacji - idea i instrumentalizacja. Socjologiczne studium krytyczne. Szczecin: Wydawnictwo Naukowe USz.

Kozielecki, J. (2002). Teoria czynności a psychotransgresjonizm. In: I. Kurcz, \& D. Kądzielawa (Eds.), Psychologia czynności. Nowe perspektywy (pp. 20-33). Warszawa: Wydawnictwo Naukowe Scholar.

Kwiatkowska, H. (2007). Tożsamość wychowawcy. In: M. Dudzikowa, \& M. Czerepaniak-Walczak (Eds.), Wychowanie. Pojęcia - Procesy - Konteksty. Vol. 3 (pp. 17-42). Gdańsk: GWP.

Lofland, J., Snow, D.A., Anderson, L., \& Lofland, L.H. (2009). Analiza układów społecznych. Przewodnik metodologiczny po badaniach jakościowych. Trans. A. Kordasiewicz, S. Urbańska, \& M. Żychlińska. Warszawa: Wydawnictwo Naukowe SCHOLAR.

Łukasik, J.M. (2018). Rozwój osobisty nauczyciela - nieobecna kategoria. Ruch Pedagogiczny, 2, pp. 29-37.

Madalińska-Michalak, J. (2016). Wspólnoty praktyków a granice uczenia się nauczycieli w szkole. Rola dyrektora szkoły. In: A. Minczanowska, A. Szafrańska-Gajdzica, \& M.J. Szymański (Eds.), Szkoła. Wspólnota dq̨żeń? (pp. 48-61). Toruń: Wydawnictwo Adam Marszałek.

Mahlios, M., Massengill-Shaw, D., \& Barry, A. (2010). Making Sense of Teaching through Metaphors: A Review across Three Studies. Teachers and Teaching: Theory and Practice, 16(1), pp. 49-71. DOI: 10.1080/13540600903475645.

Michalak, J. (2007). Uwarunkowania sukcesów zawodowych nauczycieli: studium przypadków. Łódź: Wydawnictwo UŁ.

Morgan, G. (2005). Obrazy organizacji. Trans. Z. Wiankowska-Ładyka. Warszawa: Wydawnictwo Naukowe PWN.

Nowosad, I. (2018). Kultura szkoły versus klimat szkoły. Kultura i Edukacja, 1, pp. 41-53. DOI: 10.15804/kie.2018.01.03.

Nowosad, I. (2019). Kultura szkoły w rozwoju szkoły. Kraków: Oficyna Wydawnicza Impuls. 
Ollivier, B. (2010). Nauki o komunikacji. Teoria i praktyka. Trans. I. Piechnik. Warszawa: Oficyna Naukowa.

Pawłowska, B. (2012). Kultura organizacji (kultura organizacyjna). In: K.T. Konecki, \& P. Chomczyński (Eds.), Słownik socjologii jakościowej (pp. 158-162). Warszawa: Difin.

Piorunek, M. (2009). Kariery zawodowe ludzi na etapie średniej dorosłości. Ciągłość i zmiana na polskim rynku pracy. In: M. Piorunek (Ed.), Człowiek w kontekście pracy. Teoria - empiria - praktyka (pp. 301-323). Toruń: Wydawnictwo Adam Marszałek.

Potulicka, E. (2016). Zmiana koncepcji kształcenia nauczycieli jako podstawa reform edukacji. Studia Edukacyjne, 38, pp. 215-226. DOI: 10.14746/se.2016.38.13.

Tołwińska, B. (2011). Relacje międzyludzkie w kulturze szkoły sprzyjającej uczeniu się. In: A. Cudowska (Ed.), Kierunki rozwoju edukacji w zmieniajq̨cej się przestrzeni społecznej. Księga Jubileuszowa dedykowana profesorowi doktorowi habilitowanemu Michałowi Balickiemu (pp. 536-543). Białystok: Trans Humana Wydawnictwo Uniwersyteckie. 